\title{
Innovative development of regions of Russia: opportunities and barriers
}

\author{
Vladimir Tikhiy \\ Institute Of Economics and Management \\ Department of Innovatics and applied Economics \\ Orel state University the name of I. S. Turgenev \\ Orel, Russia \\ E-mail: tikhiivi@yandex.ru
}

\author{
Olga Koreva \\ Institute Of Economics and Management \\ Department of Innovatics and applied Economics \\ Orel state University the name of I. S. Turgenev \\ Orel, Russia \\ E-mail: olga_koreva@mail.ru
}

\begin{abstract}
This article proves that one of the main conditions of overcoming technological inferiority and modernization of the Russian economy is vigorous innovative activity since many branches of production have considerably exhausted both intensive and extensive possibilities of development. To reinforce innovative activity there must be innovative potential of regions. Innovative potential of regions is a key factor to achieving economic growth and improving quality of life of the population. The article suggests methodology of integral evaluation of innovative potential of the regions which allows to estimate the innovative development level of territories and to carry out interregional comparisons.
\end{abstract}

Keywords - innovative development of regions, competitiveness of the region, methodology of innovative potential integral evaluation of the region

\section{INTRODUCTION}

Nowdays the only way of economy development in the Russian Federation is an innovative one. Due to that innovative processes in Russia and how they are developing, is the most prior direction of the state economic policy. First of all, it is caused by the fact that in the conditions of globalization and formation of economy, progress of world scientific and technical leaders is defined by effective integration of science, education and business. The economies of these countries do not stand still, they are being modernized and this leads to significant changes in all spheres of activities on the basis of innovative development.

One of the main conditions of overcoming technological inferioriry and modernization of the Russian economy is innovative activity as many branches of production have considerably exhausted both intensive, and extensive possibilities of development. However, the economy of Russia has the following competitive advantages which should be used:

- large reserves of mineral raw materials and fuel and energy resources;

- scientific and technical potential;

- capacious domestic market;

- high education level of the population and qualification of labor at a rather low level of compensation.

Improving the competitiveness of the Russian economy is connected with introduction of new technologies in production, expansion of innovative goods and services production, which have better consumer properties and are able to carry out successful competition on the domestic and foreign market with foreign counterparts.

Complex development of domestic productions and territories to the level of their competitiveness in the world has to become a strategic objective of development of innovative activity and innovative economy formation in our country for the next few years.

The region's competitiveness is determined by a large number of factors. The region's competitiveness is determined by its ability to attract business and improve the quality of life of the population (the competitiveness of the population). The increase in appeal of the region is possible on the basis of effective use of the available objective advantages and creation of conditions for their emergence and development [1].

Possibilities for innovative development of regions are extensive, however, there are various barriers and factors defining development of the region. The conditions of innovative development in the regions are determined by the characteristics of the regional economy. The factors that determine the development of the region, include, for instance, population density and existence of free territories. For example, in Russia there are many regions with low population density and extensive territory. The maintenance of these territories, as a rule, appears to be costly. There is no univocal attitude to this fact. On the one hand, the exploration of natural resources, industrial improvement demand creation of expensive provision systems. On the other hand, the development of these territories require capital investments in the modern equipment in order to implement the activities necessary for the region.

Research of the characteristics of innovative potential of the region was studied in many works of domestic and foreign scientists such as N. N. Mitina [2], S. B. Savchuk [3], C. Freeman [4], O. N. Izyumova [5].

Now, the problem of complex evaluation of innovative potential of the region has aquired a special relevance. This problem occupies scientists of various domestic and international organizations.

On the basis of the comparative analysis of regions innovative potential evaluation methodologies by V.A. Sergeyev [6], R. N. Ushakov [7], O. V. Mamay [8], V.I. 
Tikhy, O.V. Koreva [9], Higher School of Economics [10], Expert RAEX [11], it has become clear that there is no consistent methodological approach to complex assessment of region's innovative potential.

The innovation of the region is defined by its capacity for self-updating, adaptation to the changing conditions and generation of products of scientific and technical progress.

As international experience shows, sustainable production development and also maintenance of its competitiveness with commitment to a long-term perspective, depends, first of all, not only on resource opportunities but mostly on innovations as they are. [12].

Thus, strengthening the region's competitive advantages and fostering innovation can be achieved through the creation of effective forms of support for science and innovation.

Realization of complex innovative projects in the regions demands legal and financial state support.

\section{RESEARCH METHODS}

Implementation of innovative activity requires presence of innovative potential. Innovative potential of the region allows to estimate the possibilities of innovative activity of the territory and to develop strategy for further innovative development.

The authors' research has developed a methodology of integral evaluation of innovative potential of the region on the basis of domestic and foreign methods [13].

The basis of this methodology is a system of indicators, grouped into five blocks, namely:

1) socio-economic conditions of innovative activity (gross regional product (GRP) per one person employed in the economy of the region; the average income of the population; investments in fixed capital, the coefficient of renewal of fixed assets);

2) labour potential (the expenditures of the consolidated budget of the subject of Federation on education; the number of staff involved in scientific research and development; the number of researchers with a scientific degree, graduate from graduate school; organizations conducting training of postgraduate students; the number of students enrolled in bachelor, specialist, master);

3) financial potential (domestic expenditures on research and development, \% of GRP; expenditure on technological innovation (TI); the intensity of expenses on TI; costs in the information and communication technology (ICT));

4) production and technological potential (the share of organizations performing TI; number of created advanced production technologies; number of used advanced industrial technologies; the share of organizations engaged in technological, organizational and marketing innovations in the reporting year, the total number of the surveyed organizations);

5) scientific and technical potential (the number of organizations performing Research and Development, R\&D; admission of patent applications; developed advanced production technology; the issue of the security documents; the volume of innovative goods, works, services; organizations, to carry out innovations that provide increased environmental safety in the production process of goods, works, services).

On the basis of statistical data published on the website of the Federal State Statistics Service [14], and applying the proprietory technology, detailed in [13] estimation of innovative potential of regions of the Central Federal district was integrated for the period from 2012 to 2016.

The analysis produced valuation indicators by the method of linear scaling and the calculation of a weighted average of all blocks. Then the integral indicator of innovation potential of regions of Central Federal district was determined on the basis of the integrated values for each selected block (a formula weighted arithmetic average was used ).

The results are presented in table 1.

TABLE I. INTEGRAL INDEX OF INNOVATIVE POTENTIAL OF REGIONS OF THE CENTRAL FEDERAL DISTRICT IN 2012 - 2016, IN UNITS

\begin{tabular}{|l|l|l|l|l|l|l|}
\hline \multirow{2}{*}{ No } & \multirow{2}{*}{ Regions } & \multicolumn{5}{|c|}{ years } \\
\cline { 3 - 7 } & 2012 & 2013 & 2014 & 2015 & 2016 \\
\hline 1 & Belgorod region & 0,195 & 0,183 & 0,176 & 0,196 & 0,202 \\
\hline 2 & Bryansk region & 0,104 & 0,106 & 0,097 & 0,096 & 0,159 \\
\hline 3 & Vladimir region & 0,192 & 0,195 & 0,198 & 0,200 & 0,234 \\
\hline 4 & Voronezh region & 0,171 & 0,171 & 0,196 & 0,192 & 0,247 \\
\hline 5 & Ivanovo region & 0,116 & 0,138 & 0,139 & 0,131 & 0,136 \\
\hline 6 & Kaluga region & 0,152 & 0,178 & 0,215 & 0,194 & 0,217 \\
\hline 7 & Kostroma region & 0,149 & 0,112 & 0,098 & 0,073 & 0,085 \\
\hline 8 & Kursk region & 0,135 & 0,123 & 0,142 & 0,147 & 0,146 \\
\hline 9 & Lipetsk region & 0,213 & 0,208 & 0,206 & 0,222 & 0,249 \\
\hline 10 & Moscow region & 0,329 & 0,336 & 0,341 & 0,348 & 0,372 \\
\hline 11 & Oryol region & 0,121 & 0,117 & 0,118 & 0,125 & 0,135 \\
\hline 12 & Ryazan region & 0,165 & 0,172 & 0,178 & 0,192 & 0,194 \\
\hline 13 & Smolensk region & 0,131 & 0,135 & 0,132 & 0,128 & 0,142 \\
\hline 14 & Tambov region & 0,068 & 0,084 & 0,097 & 0,105 & 0,165 \\
\hline 15 & Tver region & 0,123 & 0,092 & 0,094 & 0,079 & 0,084 \\
\hline 16 & Tula region & 0,129 & 0,152 & 0,158 & 0,156 & 0,183 \\
\hline 17 & Yaroslavl region & 0,208 & 0,225 & 0,216 & 0,228 & 0,222 \\
\hline 18 & Moscow & 0,921 & 0,938 & 0,925 & 0,924 & 0,936 \\
\hline
\end{tabular}

\section{RESULTS OF A RESEARCH}

The lowest level of the indicator of innovative potential in 2012 was observed in the Tambov region which equaled to 0,068 units, but by 2016 there had been a noticeable increase up to 0,165 units. In 2016 the lowest level was recorded in the Tver region, equal to 0,084 units. Also a low level of this indicator throughout the analyzed period was observed in the Kostroma and Bryansk regions.

Taking into consideration the data of an integrated indicator it is possible to analyse as points of innovative growth in the Central Federal district (CFD) were displaced. Year 2012 was chosen as a comparative base.Calculation data has shown that the line-up of the first three in the rating of the regions having the largest innovative potential remained constant in 2016 when compared to 2012. Moscow, the Moscow and Lipetsk regions have become a fixture on these positions. Also rather high positions in this rating in 2016 are taken by the Voronezh, Vladimir, Yaroslavl and Kaluga regions.

Seven regions (Voronezh, Vladimir, Kaluga, Tula, Tambov, Bryansk, Ivanovo regions) have improved the positions, and other eight regions (Yaroslavl, Belgorod, Ryazan, Kursk, Smolensk, Oryol, Kostroma, Tver regions) have fallen in rating.

The most noticeable growth of innovative potential was in the Tambov region - transition from the 18th place to the 11th place, in the Bryansk region - from the $17^{\text {th }}$ to the $12^{\text {th }}$, in the Voronezh region - from the $7^{\text {th }}$ to the $4^{\text {th }}$, in the Tula region from the $13^{\text {th }}$ to the $10^{\text {th }}$. The movements of the remaining three regions in a rating scale were insignificant and count 1-2 
positions. It is possible to designate the Vladimir region, (plus 1), the Kaluga region (plus 2) and the Ivanovo region (plus 1) to them.

Innovative growth of the Tambov region is determined by increase in values of subindexes of financial and production and technological potential.

Besides, the Tambov region's position change in the general innovative rating of CFD is affected by the change of several indicators: the growth of physical volume of gross regional product, as well as the growth of investment in fixed capital per capita, and the increase in the intensity of expenditures for technological innovation.

It is to be noted that the level of innovative potential in 2016 compared to 2012 increased by almost 3 times and amounted to 0,165 units. (this is the highest growth among the regions of Central Federal District).

The most considerable innovative decrease is observed in the Kostroma region - transition from the $10^{\text {th }}$ to the 17 th place in the general rating and also in the Tver region - from the $14^{\text {th }}$ to the $18^{\text {th }}$.

Recession in these regions is connected with reduction of production and technological and scientific and technological potential. What is more, the number of the technologies being used in the Kursk region decreased by 263 in 2016 in comparison with 2012.

The number of the granted patents in the Smolensk region was reduced by 19 units.

The movement on a rating scale of the Yaroslavl region was insignificant (minus 2).

In general, the number of regions with the high and average level of innovative potential for the studied period has increased almost on a third, and with low - has decreased three times that demonstrates some increase in innovative activity at the regional level.

Reduction of values of above-mentioned indicators is caused by currency crisis of 2014-2015 and also by the policy of sanctions and anti-sanctions.

The financial condition of the enterprises has worsened as demand for innovative goods, works, services was reduced. Consequently there was slow development of innovative potential of regions in Central Federal district (CFD). Currently, there is a gradual increase of innovative potential, but this process occurs quite slowly, which is due to the current market conditions and socio-economic situation in the country as a whole.

\section{CONCLUSIONS AND PROSPECTS OF DEVELOPMENT OF THIS DIRECTION OF RESEARCHES}

The innovative economy model in the regions involves the creation of effective forms of support for science and innovation, because the implementation of complex and innovative projects often requires government support.

Regional governing bodies need to form special approach to management and development of innovative activity in the region, namely:

- to determine "points of growth" for each specific region, the priority sectors and activities, allowing to realize the competitive advantages of the territory;

- to produce timely, quality innovative business projects and effective investment projects on their basis;

- to promote attraction of direct foreign and national investment in the region's enterprises and to promote their implementation;
- directly participate in the most effective and socially important regional investment projects with the use of tender and contract systems for their implementation;

- to strive to improve the level of financial autonomy of micro-regions (municipalities) based on the use of their resource potential and competitive advantages.

Central Federal District has considerable innovative potential allowing it to take a more noticeable place in Russia and, in some directions, in the world.

The research of innovative potential of regions of CFD has shown that development of innovative processes happens unevenly: there are regions (Moscow, the Moscow region) which in many respects advance the regions innovative "outsiders" (The Tver, Kostroma regions) .

In 2015 a negative dynamics of indicators values defining innovative development was observed caused by currency crisis of 2014-2015.

Now there is a gradual accumulation of innovative potential, but this process is developing slowly due to the developed market condition and an unstable social and economic situation in the country.

The innovative potential analysis of the region, where the authors of this article live, was quite interesting in its own right.

As regression analysis found that gross regional product of the Oryol region for the period from 2012 to 2016 to a greater extent was influenced by $\mathrm{R} \& \mathrm{~d}$ expenditures, receipt of patent applications, the number of used advanced production technologies.

However, among the three variables, one indicator of $\mathrm{R} \&$ $\mathrm{d}$ expenditure is not statistically significant.

Thus, the main feature of the innovative development of Russian regions is that this process is distributed across the regions unevenly. The divergence in indicators of regions will become less noticeable only in case the state actively participates in management and financing of innovative activity.

The state, first of all, needs to motivate all subjects of economy so that they have a desire and aspiration to develop innovative activity. To receive an additional boost, regions need also to cooperate with sectors of researches and scientific developments, relying on the created infrastructure in the region.

Often, a region has a high level of education of the population and a large number of students and, however, almost the lowest indicators in the field of innovative activity.

Again, oneshould bear in mind that even if there is a sufficient number of qualified personnel in the region, it is impossible to build a knowledge economy without having the objects of innovation and information infrastructure.

\section{REFERENCES}

[1] S.Yu. Glazyev, D.S. Lvov, G.G. Fetisov. Evolution of technical and economic systems: opportunities and boundaries of the centralized regulation. M.: Science, 2007. 417 p.

[2] N.N. Mitina, E.A. Choubina. Stimulation of innovative activity at the level of the region//Problems of the theory and practice of control, 2014, No 6, pp. 38-41.

[3] S.B. Savchuk. Entity and structure of innovative capacity of the region//Scientific bulletin of YuIM. 2014, No 3, pp. 40-44.

[4] C. Freeman. The National Systems of Innovation in historical perspective//Cambridge journal of economics, 1995, No 19, pp. 5-24.

[5] O.N. Izyumova. Economic entity and nature of innovative potential and investment attractiveness of the region//UEKS, 2011, No 34, pp. 30-35. 
[6] V.A. Sergeyev, V.V. Skobeeva, K.E. Bashirov. Assessment and analysis of innovative capacity of the Ulyanovsk region//Innovations, 2008, No 1, pp. 93-99.

[7] R.N. Ushakov. Methodological approach to assessment of innovative potential//Service in Russia and abroad, 2011, No 4, pp. 142-147.

[8] O.V. Mamay, I.N. Mamay. System of indicators of innovative development of an agrarian sector of the region//Bulletin of the Udmurt university, 2015, No 6, pp. 33-41.

[9] V.I. Tikhy, O.V. Koreva. Methodical approaches to assessment of innovative potential of development of the territories//International scientific and practical conference "New economy: institutes, tools, trends". Orel: "Cartouche", 2017, pp. 202-207.

[10] L.M. Gokhberg. Rating of innovative development of territorial subjects of the Russian Federation: the analytical report / under the editorship of L.M. Gokhberg. M.: National research university "Higher School of Economics", 2012. 104 p.
[11] Investment ratings of regions of Russia [Online] //RAEX Rating agency [official site]. Available: https://raexpert.ru/ratings/regions (22.11.2017).

[12] National center on monitoring of innovative infrastructure of scientific and technical activities and regional innovative systems. [Online]. Available:: http://www.miiris.ru/infrastruct/view_organizations.php? mplevel=22000\&pplevel=2 (2.12.2017).

[13] V.I. Tikhy, V.B. Kirillov. Analysis of innovative capacity of regions of the $\mathrm{CFD} / / \mathrm{X}$ International scientific and practical conference "Innovative Development of the Russian Economy". Moscow: of "REU of G.V. Plekhanov", 2017, pp. 72-76.

[14] Regions of Russia. Socio-economic indexes//Federal State Statistics Service [Online]. Available: 